\title{
A Study to Assess the Effectiveness of VATM on Knowledge Regarding Malnutrition among Mothers of Under-Five Children Residing at Navanagar of Bagalkot
}

\author{
Monappa \\ M.Sc Nursing $2^{\text {nd }}$ Year \\ Dept of Paediatric Nursing \\ BVVS Sajjalashree Inst of Nursing Sciences Navanagar \\ Bagalkot Karnataka587-103
}

\author{
Prof. Sureshgouda S Patil. M.Sc (N), MBA (HM) \\ Head of Dept. \\ Dept of Paediatric Nursing
}

BVVS Sajjalashree Inst of Nursing Sciences Navanagar Bagalkot Karnataka-587 103

Dr. Deelip. S. Natekar. M.Sc (N), Ph.D. (N)

Principal

BVVS Sajjalashree Inst of Nursing Sciences Navanagar Bagalkot Karnataka-587 103.

Abstract

$>$ Aims:

The aims of this study are as follows: (1) To assess the knowledge regarding malnutrition among mothers of under-five children. (2) To assess the effectiveness of VATM on knowledge regarding malnutrition among the mothers of under-five children and (3) To find out the association between the knowledge with their selected socio-demographical variables.

\section{Materials and Methods:}

Study approach- This was a quasi-experimental survey and follow the study design as pre-experimental one group pre-test, post-test without control group. The population involved in this study was mothers of underfive children in Bagalkot. Samples are mothers of under-five children residing in Navanagar. Sample size is 100 (Total) mothers of under-five children were included in the study. Further, data were collected by structured closed ended knowledge questionnaire.

\section{$>$ Results:}

After collection, the data are organized and analyzed with the help of mean median and percentage, and the socio-demographic characteristics of mothers of under-five children were as follows: $46 \%$ of mothers of under-five children are in the age group of 20-25 years, $35 \%$ of mothers belongs to primary education, $59 \%$ of mothers are house wife, $38 \%$ of mothers are having 15,001-20,000rs, $93 \%$ of mothers are Muslims, $71 \%$ of mothers are from nuclear family, and $39 \%$ of mothers are having 2 children. Percentage wise distribution of mothers according to their knowledge shows that $46 \%$ of mothers had good knowledge followed by $36 \%$ mothers had average knowledge, $16 \%$ had poor knowledge and only $2 \%$ mothers had very poor knowledge. After VATM (post test) $86 \%$ mothers are having very good knowledge followed by $14 \%$ mothers had good knowledge and no mothers of under-five children with average, poor and very poor knowledge.

\section{$>$ Conclusion:}

After thorough analysis of the data, researcher concluded that only $46 \%$ mothers of under-five children are with good knowledge related to malnutrition. A mother with good knowledge can have healthy children. Hence more study can be conducted by using different method of teaching to achieve optimal knowledge related to malnutrition.

Keywords:- Mothers of under-five children, Knowledge, VATM, Effectiveness and socio-demographic variables.

\section{INTRODUCTION}

Malnutrition is a manmade disease which often begins in the womb and ends in the tomb. It is a global problem especially in developing countries. ${ }^{1}$ Malnutrition is one of the main causes of the death of children under the age of 5 years and is one of the most common causes of the decline in the health and life of children, which results in decreased learn ability, inefficiency and inability to acquire skills. ${ }^{2}$

Malnutrition can be defined as a group of clinical conditions that results from varying degree of protein deficiency and energy (calorie) inadequacy. ${ }^{3}$

Stunting, wasting and underweight are among those anthropometric indicators are commonly use to measure malnutrition in a population of under-five children. ${ }^{4}$

- Stunting refers to a child who is too short for his or her age.

- Wasting refers to a child who is too thin for his or her height.

- Underweight refers to child who has less weight than normal. $^{5}$ 
The 2019 GHI (Global Hunger Index) measured hunger in 117 countries where the assessment is most relevant and where data on all four component indicators are available. These indicators are proportion of underweight, and undernourished, mortality rate, stunted children under five years of age. On account of its huge populace, India's GHI pointer esteems oversizedly affect the marker esteems for the area. India's kid wasting rate is very high at $20.8 \%$-the most elevated squandering pace of any nation in this report for which information or evaluations were accessible, the report said. Stunting rate, $37.9 \%$ is also categorized as very high in terms of its public health signature. In India, 9.6\% of all children between 6 \& 23 months of age are fed a minimum acceptable diet. ${ }^{6}$ According to a UNICEF report 2019; Malnutrition caused $69 \%$ of passings of kids beneath the age of five in India. This incorporates stunting [35\%], wasting [17\%] \& overweight [2\%]. ${ }^{7}$ Acc. to the Global nutrition Report 2018, India is confronting a significant ailing health emergency as it holds very nearly $3 \%$ of world's weight for stunting. With 46.6 million [31\%] children who are stunted, India additionally built for 25.5 million youngsters who are wasted, trailed by Nigeria [3.4 million] and Indonesia [3.3 million]. ${ }^{8}$

PEM has been marked as one of the major nutritional problem among children in India. Since the mothers were the primary care takers of children, if they possess adequate knowledge on food and nutrition of children, they can be prevented from protein energy malnutrition. ${ }^{9}$

In north Karnataka where people especially in rural areas have still not come out of the ritual superstitious practices, the malnutrition has rooted badly deep. In Bagalkot district stunted, wasted and under weight is $36.2 \%, 26.1 \%$ and $35.2 \%$ respectively. ${ }^{10}$

A pre-experimental study conducted to assess the effectiveness of Video Assisted Teaching Module regarding malnutrition among mothers of under-five children residing at selected slum areas of Bhopal [2019]. 30 subjects were selected by purposive sampling technique. Quantitative approach with one group pretest, posttest research design was utilized.. Result shown that before administration of the structured teaching programme $18(40 \%)$ mothers had poor knowledge $15(33.3 \%)$ with average knowledge and $12(26.7 \%)$ had good knowledge. After VATM education 12[26.7] had poor knowledge, $21[46.7 \%$ ] had average knowledge \& 12[26.7\%] had good knowledge. The findings of the present study were analyzed and discussed with the findings of other similar studies confirmed That (VATM) regarding malnutrition was effective. It's increasing the knowledge of mothers of under 5 year children. ${ }^{11}$

Hence with the aim to assess the effectiveness of VATM on knowledge regarding malnutrition among mothers of under-five children residing at Navanagar of Bagalkot was planned.
Aims

The aims of this study are as follows:

- To assess the knowledge regarding malnutrition among mothers of under-five children.

- To assess the effectiveness of VATM on knowledge regarding malnutrition among the mothers of under-five children.

- To find out the association between the knowledge with their selected socio-demographical variables.

\section{MATERIALS AND METHODS}

The present study was conducted on a quasiexperimental approach and pre-experimental one group pretest, post-test without control group design. The target population is mothers of under-five children in Bagalkot district. Accessible population is mothers of under-five children in Navanagar was selected by a lottery method of simple random sampling technique and 100 mothers of under-five children were selected. The data were collected by structured closed ended knowledge questionnaire. Data analysis and interpretation were performed using descriptive such as frequency distribution, mean, median, percentage, and inferential statistics such as Chi-square, Fisher's exact test.

\section{RESULTS}

> Part A: Description of demographic characteristics of the mothers of under-five children.

Percentage-wise distribution of mothers of under-five children according to their age evident that majority $46 \%$ of mothers were in the age group of $20-25$ years, $21 \%$ were in the age group of $26-30$ years, $17 \%$ were in the age group of $31-35$ years and $16 \%$ were 36 years and above.

Percentage-wise distribution of mothers of under-five children according to their education depicts that the majority $35 \%$ of mothers had primary education, $30 \%$ had no formal education, $15 \%$ were with secondary education, $12 \%$ were with PUC, and $08 \%$ were with degree $\&$ above.

Percentage-wise distribution of mothers of under-five children according to their occupation depicts that the majority $59 \%$ of mothers were house wife, $14 \%$ were agriculturist, $11 \%$ were doing labor, $06 \%$ were with business, and $07 \%$ were with govt. and $03 \%$ with private employee.

Percentage-wise distribution of mothers of under-five children according to their family monthly income (In rupees) depicts that the majority $38 \%$ of mothers were with income of 15,001-20,000rs, $28 \%$ were with 10,001 $15,000 \mathrm{rs}, 16 \%$ were with $5,000-10,000 \mathrm{rs}, 15 \%$ were with 20,001-25,000rs, and $03 \%$ were with 25,001rs \& above.

Percentage-wise distribution of mothers of under-five children according to their religion depicts that the majority 93\% of mothers were Hindu, $06 \%$ were Muslim and $01 \%$ were Christian. 
Percentage-wise distribution of mothers of under-five children according to their type of family depicts that the majority $71 \%$ of mothers were from nuclear family, $28 \%$ were from joint family and $01 \%$ were from extended family.

Percentage-wise distribution of mothers of under-five children according to their no. of children depicts that the majority $37 \%$ of mothers were having 2 children, $33 \%$ were having 3 children, $24 \%$ were having 1 child and $06 \%$ of mothers were having $4 \&$ above children.

Part B: Assessment of knowledge regarding malnutrition among mothers of under-five children.

Percentage distribution of mothers according to their knowledge level reveals that $46 \%$ mothers were having good knowledge, whereas $36 \%$ had average knowledge, $16 \%$ had poor knowledge and only $2 \%$ mothers had very poor knowledge. [Table 1]
Part C: Assessment of the effectiveness of the VATM on knowledge regarding malnutrition among mothers of under-five children.

After VATM (post test) $86 \%$ mothers were having very good knowledge, whereas $14 \%$ mothers had good knowledge and there are no mothers of under-five children with average, poor and very poor knowledge regarding malnutrition. [Table 2]

Part D: Association between the knowledge with their selected socio-demographic variables.

Chi-square test and Fisher's exact test is used to find the association between the knowledge with their selected socio-demographic variables. The test results reveals that the calculated chi-square value for the socio-demographic variables like age, education, occupation, family monthly income, religion, type of family and no. of children in the family are $0.691,0.251,0.005,0.008,1,0.0002$ and 0.827 . The chi-square table value is 3.84 . Hence the Chi square calculated values are lesser than Chi square table values. This indicates there was no significant association found between the above said selected socio-demographic variables with their knowledge on malnutrition. $\mathrm{P}<0.05$. [Table 3]

\begin{tabular}{|c|c|c|c|c|}
\hline \multirow{2}{*}{ Sl. No } & \multirow{2}{*}{ Range of score } & \multirow{2}{*}{ Knowledge of mothers } & \multicolumn{2}{|c|}{ Pre-test } \\
\cline { 3 - 5 } & & & Frequency & \% \\
\hline $\mathbf{1 .}$ & $\mathbf{0 - 5}$ & Very poor & 02 & 02 \\
\hline $\mathbf{2 .}$ & $\mathbf{6 - 1 2}$ & Poor & 16 & 36 \\
\hline $\mathbf{3}$. & $\mathbf{1 3 - 1 8}$ & Average & 36 & 46 \\
\hline $\mathbf{4}$. & $\mathbf{1 9 - 2 5}$ & Good & 46 & 00 \\
\hline $\mathbf{5}$ & $\mathbf{2 6 - 3 2}$ & Very good & 00 & $\mathbf{1 0 0}$ \\
\hline
\end{tabular}

Table 1:- Frequency and percentage distribution of mothers of under-five children according to their knowledge on malnutrition. $(\mathrm{N}=100)$

\begin{tabular}{|c|c|c|c|c|c|c|}
\hline \multirow{2}{*}{ Sl. No } & \multirow{2}{*}{ Range of score } & \multirow{2}{*}{$\begin{array}{c}\text { Knowledge of } \\
\text { mothers }\end{array}$} & \multicolumn{2}{|c|}{ Pre-test } & \multicolumn{2}{c|}{ Post-test } \\
\cline { 4 - 7 } & & & Frequency & $\%$ & Frequency & \% \\
\hline $\mathbf{1 .}$ & $\mathbf{0 - 5}$ & Very poor & 02 & 02 & 00 & 00 \\
\hline $\mathbf{2 .}$ & $\mathbf{6 - 1 2}$ & Poor & 16 & 16 & 00 & 00 \\
\hline $\mathbf{3 .}$ & $\mathbf{1 3 - 1 8}$ & Average & 36 & 36 & 00 & 00 \\
\hline $\mathbf{4}$. & $\mathbf{1 9 - 2 5}$ & Good & 46 & 46 & 14 & 14 \\
\hline $\mathbf{5 .}$ & $\mathbf{2 6 - 3 2}$ & Very good & 00 & 00 & 86 & 86 \\
\hline & & TOTAL & $\mathbf{1 0 0}$ & $\mathbf{1 0 0}$ & $\mathbf{1 0 0}$ & $\mathbf{1 0 0}$ \\
\hline
\end{tabular}

Table 2:- Percentage wise distribution of study subjects according to levels of knowledge in pre-test and post-test. (N=100) 
ISSN No:-2456-2165

\begin{tabular}{|c|c|c|c|c|c|}
\hline SL. NO. & Socio-demographic variables & $\mathbf{d f}$ & $\chi^{2}$ calculated value & $\chi^{2}$ table value & Association \\
\hline 1 & Age & 1 & 0.691 & 3.84 & No significant Association \\
\hline 2 & Education & 1 & 0.251 & 3.84 & No significant Association \\
\hline 3 & Occupation & 1 & 0.005 & 3.84 & No significant Association \\
\hline 4 & Family monthly income & 1 & 0.008 & 3.84 & No significant Association \\
\hline 5 & Religion & 1 & 1 & 3.84 & No significant Association \\
\hline 6 & Type of family & 1 & 0.0002 & 3.84 & No significant Association \\
\hline 7 & No. of children in the family & 1 & 0.827 & 3.84 & No significant Association \\
\hline
\end{tabular}

Table 3:- Association between the knowledge with their selected socio-demographic variables. $(\mathrm{N}=100)$

\section{DISCUSSION}

After reviewing many studies related to mothers of under-five children knowledge regarding malnutrition and A broad it has immensely influenced me to take up the present study, The studies influenced me to conduct this present study as follows.

A pre-experimental research study conducted to assess the knowledge on protein energy malnutrition among mothers of under-five children, to determine the effectiveness information booklet on protein energy malnutrition among mothers of under-five children in selected rural communities, Nellore (2016). An evaluative study by using pre-experimental one group pretest and post-test design was used, a sample size of 100 mothers were selected by using simple random sampling technique, Semi structured questionnaire were used to collect the data and information booklet was provided and post-test level of knowledge was assessed. Data was computed by using descriptive $\&$ inferential statistics. Results shows that out of 100 mothers in pre-test $68(68 \%)$ mothers had inadequate knowledge regarding protein energy malnutrition $32(32 \%)$ with moderately adequate knowledge where as in post test 59 [59\%] subjects acquired adequate knowledge \& 36 [36\%] subjects acquired moderately adequate knowledge. Mean post-test score (38.5) was higher than the mean pretest score score (13.64). Paired ' $t$ ' value was 40.125 at $\mathrm{p}<0.05$. There was statistically significant association between pre-test level of knowledge and demographic variables of mothers such as age, educational status, no. of children, monthly income and type of family. The study concluded that the mothers were improved their knowledge with information booklet. ${ }^{12}$

A quasi-experimental research conducted to assess the knowledge of mothers of under-five children regarding protein energy malnutrition in selected rural areas in Wardha district (Maharastra) in 2016. A quasi-experimental with one group pretest \& posttest design was utilyzed. A convenient sample of 50 subjects. Results shows that in pretest $2(4 \%)$ of mothers of under-five children were having poor level of knowledge score, $76 \%$ had average and $20 \%$ of them had good level of knowledge score. The mean score of pre-test was $8.04 \pm 1.92$ whereas in post-test $13(26 \%)$ of mothers of under-five children were having good level of knowledge score, $64 \%$ had very good and $10 \%$ had excellent level of knowledge score. The mean score for the post-test was 16.18 \pm 2.31 . Significant association not found between knowledge score and selected socio demographic variables. The study recommended that same study can be done on a using structured closed ended questionnaire. ${ }^{13}$

\section{CONCLUSION}

After thorough analysis of the data, it is understood that only $46 \%$ mothers of under-five children are with good knowledge related to malnutrition. A mother with good knowledge can have healthy children. Hence more study can be conducted by using different method of teaching to achieve optimal knowledge related to malnutrition.

\section{RECOMMENDATIONS}

A similar study can be repeated in different regions of the states or nations so as to compare the results.

$>$ The same study can be replicated on a large sample to generalize the findings.

$>$ The study can be conducted by including additional demographic variables.

$>$ A similar study can be recommended by using different method of teaching.

\section{REFERENCES}

[1]. Shreevani R. Malnutrition and mental development. Published by Nightingale nursing times. 2006; 1(12): 21-22.

[2]. World Health Organization. Children: reducing mortality. Nov 20 2018. [https://www.who.int/newsroom/fact-sheets/detail/children-reducing-mortality].

[3]. Datta P, A text book of Peadiatric Nursing. 2nd ed. Ansari Road, Daryaganj, New Delhi-110002. Jaypee Brothers Medical Publishers (P) Ltd. 2009; 204. 
[4]. Janevic T, Petrovic O, et al. Risk factors for childhood malnutrition in Roma settlement, Serbia. Published by under license to BioMed Central Ltd. TBMC public health. 2010; 11(790): 509.

[5]. Sing A, Sujit K, et al. Childhood Mal. in India, perspective of recent adv. in acute diarrhoea. IntechOpen, DOI: 10.5772/intechopen. 89701. [Available from: https://www.intechopen.com/books/perspective-ofrecent-advances-in-acutediarrhea/childhoodmalnutrition-in-india]

[6]. Global Hunger Index (GHI) 2019. [Available from: https://www.livemint.com/news/india/india-facingsevere-levels-of-malnutrition-climate-change-tofurther-worsen-undernutrition-11571207482952.html]

[7]. UNICEF report. Malnutrition behind $69 \%$ deaths among children below 5 yrs in India. Oct 16, 2019. $08.26 \mathrm{PM}$.

[8]. India home to 46.6 million stunted children, a third of world's total: Global Nutrition Report 2018; 1-2.

[9]. Kaur S, Kaur B. Effect of nutritional demonstration programme (ndp) on mothers knowledge and its effect on health status of their under-five malnourished children in selected areas of Ludhiana, Punjab. Published by international journal of current advanced research. January 2018; 7(1) (C): 8908-913.

[10]. National family survey-4(NFHS-4, 2015-16). Ministry of health and family welfare. India. Aug 12, 2017.

[11]. Shrinivas C. Effectiveness of VATM regarding malnutrition in slum areas of Bopal. Published by PARIPEX - INDIAN JOURNAL OF RESEARCH. ISSN No: 2250-1991. Dec-2019; 8(12): 891-893.

[12]. Kalpana B, Indira A, et al. Study to evaluate effectiveness of information booklet on protein energy malnutrition among mothers of under-five years children in selected rural communities, Nellore. Published by international journal of recent scientific research. June 2016; 7(6): 11585-588.

[13]. Moon P, Josy S C. Knowledge of mothers of underfive children regarding PEM at selected rural areas in Wardha district, Maharastra. Published by international journal of advanced scientific research. ISSN: 2456-0421; October 2016; 1(7): 01-03. 